\title{
Evaluation of knowledge, attitude, and behavior about harmful effects of the sun and sun protection among patients attending an outpatient clinic
}

\author{
Polikliniğe bașvuran hastalarda güneșin zararlı etkileri ve korunma yolları ile ilgili bilgi, \\ tutum ve davranıșların araștırılması
}

\section{Sevim Terzi, Pınar Yüksel Bașak*, Ijlal Erturan**}

Akșehir Public Hospital, Department of Dermatology, Akșehir, Turkey

*University of Health Sciences, Kartal Dr. Lütfi Kırdar Training and Research Hospital, Department of Dermatology, İstanbul, Turkey **Süleyman Demirel University Faculty of Medicine, Department of Dermatology, Isparta, Turkey

\begin{abstract}
Background and Design: The aim of the study was to evaluate harmful effects of sun exposure and knowledge, attitude and behaviors related to sun protection among patients attending our outpatient clinic.

Materials and Methods: A total of 400 patients (171 male and 229 female) aged between 16 and 89 years were included in this study. Subjects were requested to fill out a questionnaire composed of 52 questions. In the first part of the questionnaire, patients' socio-demographic characteristics, history of sunburn, first-degree relatives with a history of skin cancer; in the second part, knowledge about harmful effects of sun and sun protection were inquired. In the third part, patient attitude and behaviors related to sun protection was evaluated.

Results: Our results revealed that $69.25 \%$ of patients had satisfactory level of knowledge. While the level of knowledge was not affected by economic status, place of residence, skin type and presence of skin cancer in participants or their first-degree relatives, it was found to be increased with increasing educational level. The patients were found to prefer avoiding mid-day sun (75.5\%) and staying in the shade (64.8\%) chiefly as sun protection methods and $45.3 \%$ of patients were found to use sunscreens. Most frequently preferred sources of information about harmful effects of the sun and sun protection methods were found to be television, magazines and newspapers (76.3\%), doctor's advice and internet, respectively.

Conclusion: Although a satisfactory level of knowledge about harmful effects of the sun and protection methods was found, it was observed that individuals could not convert their knowledge into the sun protection behavior.

Keywords: Sun protection, ultraviolet, sunscreens

Öz

Amaç: Polikliniğe başvuran hastalarda güneşin zararlı etkileri ve korunma yolları ile ilgili bilgi, tutum ve davranışların araştırıması amaçlandı. Gereç ve Yöntem: Çalışmaya yaşları 16-89 arasında değişen 171 erkek ve 229 kadın, toplam 400 hasta dahil edildi. Tüm hastalara 52 soruluk bir anket formu uygulandı. Anket formunun birinci bölümde hastaların sosyo-demografik özellikleri, güneş yanığı öyküsü, birinci derece akrabalarında deri kanseri öyküsü, ikinci bölümde güneşin zararlı etkileri ve korunma yolları hakkında bilgi düzeyleri, üçüncü bölümde ise tutum ve davranışları değerlendirildi.

Bulgular: Hastaların \%69,25'inin bilgi düzeyi yeterli bulundu. Ekonomik durum, ikamet, deri tipi, kişide ve birinci derece akrabalarda deri kanseri varlı̆̆ı bilgi düzeyini etkilemezken, eğitim seviyesi arttıkça bilgi düzeyinin arttığı görüldü. Hastaların güneşten korunma metodu olarak en çok gün ortası güneşinden kaçınma $(\% 75,5)$ ve gölgede durma $(\% 64,8)$ yöntemlerini tercih ettikleri ve \%45,3'ünün güneşten koruyucu ürün kullandığı saptandı. Güneşin zararlı etkileri ve güneşten korunma konusunda en çok bilgi edinilen kaynaklar sırasıyla televizyon, dergi ve gazete $(\% 76,3)$, doktor önerisi ve internet olarak bulundu.
\end{abstract}

Address for Correspondence/Yazışma Adresi: Pınar Yüksel Başak MD, University of Health Sciences, Kartal Dr. Lütfi Kırdar Training and Research Hospital, Department of Dermatology, İstanbul, Turkey

Phone: +90 5324223356 E-mail: pinarbasak@hotmail.com Received/Geliş Tarihi: 24.06.2015 Accepted/Kabul Tarihi: 29.02.2016

(c) Copyright 2017 by Turkish Society of Dermatology and Venereology

Turkderm-Turkish Archives of Dermatology and Venereology published by Galenos Yayınevi. 


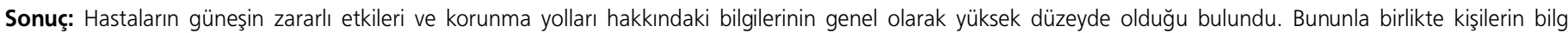
birikimini güneşten korunma davranışına dönüştürmedikleri gözlendi.

Anahtar Kelimeler: Güneşten korunma, ultraviyole, güneşten koruyucular

\section{Introduction}

The effects of sunlight on developing nevi and skin cancers show prominent differences among countries depending on personal and environmental factors. The DNA mutations caused by ultraviolet (UV) were described in 1960 and the signaling pathways targeted by specific genes and these mutations were identified in 1990s. Today, UV has been evidenced to be one of the environmental carcinogens ${ }^{1-3}$.

There has reportedly been an increase in melanoma and nonmelanoma skin cancers starting from the first half of the twentieth century. Reducing exposure to sunlight is the basic behavioral goal to prevent skin cancer development and the public should be made aware of the dangers of intense UV and educated about the ways to prevent excessive sun exposure $e^{2,4}$.

The purpose of this study was to investigate the knowledge, attitudes and behaviors related to the harmful effects of sunlight and the ways of protection in patients who presented to our outpatient clinic.

\section{Materials and Methods}

Patients aged 16 years and over who were able to read and write and who presented to the Dermatology and Venereology outpatient clinic and other outpatient clinics at our hospital between January 2013 and November 2014 were included in the study. Permission was obtained for the study from the local ethics committee of the Faculty of Medicine, Süleyman Demirel University (protocol number: 3/07.03.2012). After the patients were explained that a questionnaire would be distributed about the harmful effects of sunlight and the ways of protection and their verbal consents were obtained, the questionnaire, which took approximately 10 minutes to complete, was administered. The questionnaires were filled out through face-to-face interviews and then the patients were given a one-page informative brochure about the harmful effects of sunlight and the ways of protection.

The questionnaire consisted of 52 questions that were prepared with the help of similar studies in the literature and expert views. The questions from 1 through 9 in the questionnaire were prepared to reveal the socio-demographic characteristics of the patients, from 10 through 13 to inquire any history of sunburn, history of skin cancer in the first-degree relatives and the dermatologic characteristics of patients, from 14 through 34 to assess patients' level of knowledge and from 35 through 52 to assess their attitudes and behaviors.

There were 7 questions in the questionnaire about the harmful effects of sunlight on the skin, 7 about exposure to the sun in childhood and 7 about the use of sun protection products (SPPs), making a total of 21 questions. Nineteen questions were true/false/don't know questions and two questions were multiple choice. The knowledge level of those who gave right answers to at least 11 of the 21 questions was considered satisfactory.

There were 18 questions in the questionnaire to assess the attitudes and behaviors of the participants. In this section, the sources of information consulted about the harmful effects of sunlight and the ways of protection, the methods employed by the subjects to protect themselves and their children, if any, from sunlight, and their use of SPPs were questioned in detail.

\section{Statistical Analysis}

The data were analyzed on computer using Microsoft Excel and the SPSS statistics software version 22.0. The descriptive statistics corresponding to the data obtained were given as frequencies and percentage distributions, pie charts and column charts, and for age as mean \pm standard deviation. Cross tabulations were formed for the intercorrelated variables to explore their joint distribution. Since the variables were categorical, the correlations between them were tested using the chi-square analysis. The significance level of the correlation between the results obtained was accepted as $p<0.05$. The relationship between categorical variables was measured using the Phi and Cramer's $\checkmark$ coefficients.

\section{Results}

The study included 400 patients, 200 who presented to the dermatology outpatient clinic and 200 who presented to other outpatient clinics. The age of the patients ranged from 16 to 89 years and their mean age was 37.74 \pm 16.2 . The socio-demographic characteristics of the patients are given in Table 1.

\section{Table 1. Socio-demographic characteristics of patients}

\begin{tabular}{l|l}
$\mathbf{n}$ & $\%$
\end{tabular}

\begin{tabular}{|c|c|c|}
\hline \multicolumn{3}{|l|}{ Gender } \\
\hline Female & 229 & 57.2 \\
\hline Male & 171 & 42.8 \\
\hline \multicolumn{3}{|l|}{ Education level } \\
\hline Primary school & 142 & 35.6 \\
\hline High school & 84 & 21 \\
\hline University & 174 & 43.5 \\
\hline \multicolumn{3}{|l|}{ Marital status } \\
\hline Married & 259 & 64.8 \\
\hline Single & 141 & 35.3 \\
\hline \multicolumn{3}{|l|}{ Residence } \\
\hline City & 231 & 57.8 \\
\hline District/village & 169 & 42.3 \\
\hline \multicolumn{3}{|l|}{ Economic level } \\
\hline Very low/low & 39 & 9.8 \\
\hline Middle & 336 & 84 \\
\hline Very high/high & 25 & 6.3 \\
\hline \multicolumn{3}{|l|}{ Profession } \\
\hline Student/public servant/healthcare professional & 191 & 47.8 \\
\hline Housewife/retired & 131 & 32.8 \\
\hline Free lance/farmer/worker & 78 & 19.6 \\
\hline
\end{tabular}


The study group consisted of 171 males (42.8\%) and 229 females with $(57.2 \%)$ and $64.8 \%$ of paricipants were married. $25.3 \%$ of patients were primary school graduates, $10.3 \%$ were secondary school graduates, $21 \%$ were high school graduates, and $43.5 \%$ of them were university graduates or students. Of the subjects, $6.3 \%$ had Fitzpatrick skin type 1, 23.3\% - Fitzpatrick skin type 2 and 66\% had Fitzpatrick skin types 3 and 4 . It was found that $57.8 \%$ of the patients lived in cities, $30.8 \%$ in districts and $11.5 \%$ in villages. Of the participants, $84 \%$ stated that their economic status was middle, 9.3\% - low, 6\% high, $0.5 \%$ - very low and $0.3 \%$ had very high economic status. It was reported that $81 \%$ of the patients worked in closed environments and $19 \%$ in open areas. A history of sunburn was reported by $76 \%$ of the subjects, but no statistically significant correlation was found between history of previous sunburn and knowledge level ( $p<0.05)$.

$69.25 \%$ of subjects had sufficient knowledge on the harmful effects of sunlight and the ways of protection. We observed that although women gave better responses to the questions requiring knowledge, no statistically significant correlation was found between gender and patient knowledge level ( $p>0.05$ ). 13.9\% of women and $18.7 \%$ of men stated that they had sunbath or attended solarium for tanning. No statistically significant correlation was found between gender and having sunbath/attending solarium for tanning ( $p>0.05)$.

A statistically significant correlation was found between the patients' age and the level of their knowledge on the harmful effects of sunlight and the ways of protection and as the mean age of patients increased, the level of their knowledge on the harmful effects of sunlight and the ways of protection decreased $(p<0.001)$. There was also a statistically significant correlation between education level and knowledge level and as education level increased, knowledge level also increased $(p<0.001)$.

Of the participants, $25.8 \%$ were students and $23.8 \%$ were housewives. The rate of knowledge level sufficiency in relation to the harmful effects of sunlight and the ways of protection was $85.4 \%$ in the student group, while the farmer group had the lowest rate with $45.8 \%$.

The knowledge level was found sufficient in $68.5 \%$ of those who had some skin disease and $70 \%$ of those who had no skin disease. No statistically significant correlation was found between the presence of a skin disease and the patients' level of knowledge on the harmful effects of sunlight and the ways of protection ( $p>0.05$ ).

The patients were found to prefer mostly the methods of avoiding midday sun exposure (75.5\%) and staying in the shade $(64.8 \%)$ to

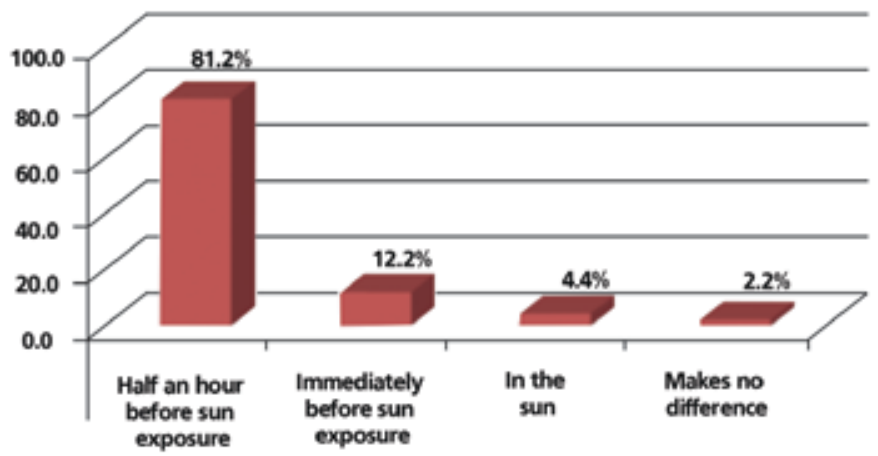

Figure 1. Patients' ways of applying sun protection products during the day protect from the sun. The most widely used physical protection method was wearing a hat with $49.5 \%$. As the patients' education level decreased, the rate of their taking no measures for protection from the sun increased in a statistically significant way $(p=0.032)$.

SPPs were used by $45.3 \%$ of the patients while $54.7 \%$ stated that they did not use any SPPs. Lacking the habit was shown at the highest rate as the reason for not using SPPs (61.8\%). Of the patients using SPPs, $64.7 \%$ were female and $35.3 \%$ male, and the difference was found to be statistically significant $(p=0.007)$. The patients' use of SPPs was also found to have a statistically significant correlation with education level $(p<0.001)$, age $(p<0.001)$, marital status $(p<0.001)$, economic level $(p=0.002)$, residence $(p<0.001)$, and the level of the subjects' knowledge on the harmful effects of sunlight and the ways of protection $(p<0.001)$. No statistically significant correlation was found between the patients' history of sunburn $(p=0.25)$ or their skin type $(p=0.645)$ and use of SPPs.

The rate of patients who preferred SPPs with a sun protection factor (SPF) 30 and over was $60.2 \%$. Of the patients who used SPPs, $52.5 \%$ stated that they used SPPs only when they would go out in the sun, $24.9 \%$ - once in the morning, $14.4 \%$ - every $4-5$ hours and $8.3 \%$ used every 2-3 hours. When the patients using SPPs were questioned about the use of SPPs at seaside, $13.4 \%$ stated that they did not go into the sea and $70.5 \%$ that they would apply the SPP on the entire regions exposed to sunlight at the seaside. From the patients using SPPs, $81.2 \%$ stated that they would apply the SPP half an hour before going out in the sun, $12.2 \%$ - immediately before going out in the sun, and $4.4 \%$, when being in the sun (Figure 1).

When the patients with children were questioned about their sun protection methods for their children, the most preferred sun protection methods used by the parents for their children were found to be avoiding midday sun exposure (85.7\%) and staying in the shade (75.9\%) (Table 2). The physical protection methods preferred mostly by the parents for their children were wearing a hat (84.9\%), wearing sunglasses (35.5\%) and SPPs (34.7\%). Of the 243 people who had children, 34.9\% stated that they used SPPs for their child/children. As the patients' education level increased, their use of SPPs for their children also increased in a statistically significant way $(p<0.001)$. The parents were found to start using SPPs for their children mostly in their early babyhood (30.5\%).

Table 2. Methods used by patients with children to protect them from sunlight (more than one choice could be marked)

\begin{tabular}{|l|l|l|l|}
\hline \multirow{5}{*}{ Sun avoidance } & & $\mathbf{n}$ & $\%$ \\
\hline \multirow{5}{*}{ Sun protection } & Not going out in the sun & 5 & 2 \\
\cline { 2 - 4 } & Sun avoidance at midday & 210 & 85.7 \\
\cline { 2 - 4 } & Staying in the shade & 186 & 75.9 \\
\cline { 2 - 4 } & Not avoiding the sun & 5 & 2 \\
\hline & $\begin{array}{l}\text { Wearing cloths covering more of } \\
\text { the body }\end{array}$ & 77 & 31.4 \\
\cline { 2 - 4 } & Wearing a hat & 208 & 84.9 \\
\cline { 2 - 4 } & Wearing eyeglasses & 87 & 35.5 \\
\cline { 2 - 4 } & Using an umbrella & 16 & 6.5 \\
\cline { 2 - 4 } & Using sun protection products & 85 & 34.7 \\
\cline { 2 - 4 } & Taking no protective measures & 11 & 4.5 \\
\hline
\end{tabular}


Television, magazines and newspapers took the first place with $76.3 \%$ among the patients' sources of information on the harmful effects of sunlight and the ways of protecting from the sun and doctor recommendation the second place with $53.8 \%$.

While $26.8 \%$ of the patients rated themselves as being sufficient in terms of their level of knowledge on the harmful effects of sunlight on the skin and protection, $73.2 \%$ stated that they did not find their level of knowledge on this subject sufficient. From those whose level of knowledge was sufficient, $70 \%$ did not find their level of knowledge satisfactory and $19.5 \%$ of those whose level of knowledge was not sufficient, thought their level of knowledge was satisfactory.

\section{Discussion}

Exposure of human skin to environmental and artificial UV has increased due to ozone layer depletion, unnecessary use of solarium devices, and changing life styles and sports activities. Increased life span is also another important factor that increases the cumulative dose of UV5. With respect to protection from sun in our country, Filiz et al. ${ }^{6}$ assessed the knowledge, attitudes and behaviors related to protection from the sun in high school students, Kaymak et al. ${ }^{7}$ in university students, Köktürk et al. ${ }^{8}$ in patients presenting to dermatology outpatient clinics, and Ergin et al. ${ }^{9}$ in mothers with children under five years of age. Moreover, Kaptanoğlu et al. ${ }^{10}$ have reported the findings in primary school children and their families in the Turkish communities in Turkish Republic of Northern Cyprus on similar subjects. In this study, we aimed at broadening the parameters for knowledge, attitudes and behaviors to obtain more detailed results.

Similar to that in a study by Yan et al. ${ }^{11}$, we also concluded in our study that the level of knowledge of patients presented to the outpatient clinic about the harmful effects of sunlight and the ways of protection was generally high. We also found that the level of knowledge of patients consulting the outpatient clinic on the harmful effects of sunlight and the ways of protection increased as their education level increased and decreased as their mean age increased. The fact that as the mean age of the participants increased the mean education level dropped may have produced this result. It was also reported in another study that the parents with high level of education were more knowledgeable about protection from the sun and demonstrated more conscientious behaviors ${ }^{10}$. The knowledge level of singles turning out to be significantly higher compared to married subjects can be explained by the fact that the group comprised of singles had a higher level of education. Not having been able to establish a correlation between history of previous sunburn or skin type and the knowledge level of the patients did not meet our expectations that subjects who have had sunburns and those with light skins would be more knowledgeable about protection from the sun.

Stanton et al. ${ }^{12}$ found that women had a higher level of knowledge about skin cancers and protection from the sun than men. Although we also found in our study that women had higher level of knowledge than men on the harmful effects of sunlight and the ways of protection, the difference was not statistically significant, but the rate of tanning behavior was found higher in men. This result may be associated with women's level of knowledge on the harmful effects of sunlight and the ways of protection being higher even though there was no statistically significant difference in our study. Similarly, although female students gave better responses to the questions related to the harmful effects of sunlight in the study of Kaymak et al. ${ }^{7}$, they also found no statistically significant difference between them and male students.

In their study they made in Northern Ireland to investigate the knowledge, attitudes and behaviors related to protection from the sun, Owen at al. ${ }^{13}$ found that the level of knowledge in males in the 1625 age group and in those older than 65 was statistically significantly lower than in other age groups. Unlike their study, we found in our study that the level of knowledge in patients in the 16-24 and 25-44 age groups were statistically significantly higher than in the 45-64 age group and in those older than 65 . This can be explained by the fact that patients in the 16-24 age group who took part in our study had a higher level of education.

We found in our study that the subjects tended to perform more the acts of not going out in the sun at all, avoiding the sun at midday and staying in the shade as their sun avoidance behaviors rather than wearing more covering clothes for protection from the sun, wearing hats and wearing sunglasses. Avoiding the sun at midday was found as the most frequently used sun protection method in these patients. This can be explained by the fact that the physical methods such as wearing hats and sunglasses, and using SPPs are more difficult to implement in practice. Similarly, Kaymak et al. ${ }^{7}$ reported in their study that the sun protection method most widely used by those who cared about protection from the sun was not going out in the sun between 10:00 and 16:00 hours. Köktürk et al. ${ }^{8}$ also found that not going out in the sun between 10:00 and 16:00 hours was practiced at a rate of 53\%. In our study, the use of SPPs were found to be significantly higher in those who had a higher level of education, younger age, in women and singles, in those with higher economic level, those living in cities, and those with a higher level of knowledge on the harmful effects of sunlight and the ways of protection. It has been reported in similar studies that the rate of using SPPs significantly increases in those with higher levels of education and monthly income and in women ${ }^{8,14-17}$. The results of a survey by Yurtseven et al. ${ }^{17}$ administered to the students in vocational schools of health showed that use of SPPs was higher in female students. In our study, use of SPPs was found higher in the 1624 age group and in females. Although we found the rate of using SPPS lower in the similar age group compared to the study of Yurtseven et al. ${ }^{17}$, this may be due to the fact that students of vocational schools of health had higher level of awareness about protection from the sun. While forgetfulness was shown as the major handicap in the use of SPPs in a study by Lee et al. ${ }^{14}$, the results of our study showed that lack of habit was the major handicap in the use of SPPS.

In a study, the rate of using SPPs with a SPF less than 15 was $8.9 \%$ and the rate of using SPPs with a SPF over 30 was $6.1 \% 7$. We found in our study that the rate of using SPPs with a SPF less than 15 was $3.3 \%$ and those with a SPF over 30 was $60.2 \%$, which may be attributed to the fact that people started to perceive in recent years that as the factor level increased, the effectiveness of the product in protection from the sun also increased and for this reason, people tend to use sun creams with higher factors.

Compatible with studies by Hutchinson et al. ${ }^{18}$ (44\%) and FernandezMorano et al. ${ }^{19}(47.8 \%), 44.3 \%$ of subjects included in our study used 
SPPs. In their study carried out in Australia, Pruim et al. ${ }^{20}$ reported that $61 \%$ of subjects had repeated application of SPPs. In our study, $52.5 \%$ of patients using SPPs used them only when going out in the sun, $24.9 \%$ - once in the morning, $14.4 \%$ - every $4-5$ hours and $8.3 \%$, every 2-3 hours. The body region where SPPs were applied mostly in daily life was reported to be the face by $70.2 \%$ of patients and the rate of those applying SPPs on the body regions exposed to sunlight was found to be $30.9 \%$. These results show that individuals using SPPs fall short of exhibiting repeating behavior during the day. However, we found in our study that $81.2 \%$ of those using SPPs used them half an hour before going out in the sun and $12.2 \%$ while going out in the sun. According to this result, it can be argued that the subjects participating in our study were more sensitive in applying SPPs half an hour before going out as compared to the results of similar studies ${ }^{21}$.

In a study made by Ergin et al. ${ }^{9}$ with mothers having children younger than five years, the sun protection method the mothers preferred mostly for themselves was staying in the shade in $96.3 \%$ and the methods they preferred mostly for their children were light-colored clothing, keeping them in the shade and having them wear hat. Avoiding the sun at midday and staying in the shade were the sun protection methods preferred mostly in our study. The most preferred sun protection methods by the parents for their children were avoiding the sun at midday, having them wearing hat and staying in the shade. This shows that adults tend to use the sun protection methods they prefer for themselves also for their children. This highlights the importance of educating first the parents and indirectly their children so that they reflect this awareness in their daily attitudes and behaviors in order to reduce exposure to sunlight, which is very important in childhood. We also found in our study that as the level of education increased in parents, the rate of their using SPPs for their children also increased and this was statistically significant $(p<0.001)$.

While $26.8 \%$ of our study group rated their level of knowledge on the harmful effects of sunlight on the skin and protection as being sufficient, $73.2 \%$ stated that they did not find their level of knowledge sufficient. From those whose level of knowledge was sufficient, 70\% did not find their level of knowledge satisfactory and 19.5\% of those whose level of knowledge was not sufficient thought their level of knowledge was satisfactory. This may be associated with the fact that those with a low level of knowledge were not aware that they had incorrect information.

In a study, $44.5 \%$ of the participants stated that their sources of information on the ways of sun protection were television, magazines and newspapers ${ }^{10}$. Similarly, television, magazines and newspapers were in the first place among the sources of information on the harmful effects of sunlight and the ways of protection in our study. These results suggest that media organs, which hold an important place in our lives, can be effectively used for education purposes.

It was concluded in our study that the level of knowledge in patients presented to the outpatient clinics about the harmful effects of sunlight and the ways of protection was generally high. However, although the activities carried out in newspapers and television to educate the public raised awareness, they remained insufficient in promoting behavioral changes. Additionally, it is known that $80 \%$ of lifetime sun exposure occurs in childhood and development of skin cancer in later periods can be reduced by $78 \%$ in children using sun protectors routinely.
Development of skin cancers can be prevented to a large extent by avoiding the sun, using SPPs and dressing appropriately. Therefore, preventive healthcare services for protection from skin cancer should primarily focus on children. We also observed that children's sun protection behaviors change depending on the advices of their families. Families that have a high level of knowledge and protect themselves from the sun have been reported to protect their children from the sun as well ${ }^{22}$.

\section{Conclusion}

Our results suggest that it is not sufficient to educate the public about the harmful effects of the sun; they should effectively be given the consciousness for protection from the sun. We assume that both children and their families should be educated about the ways of protection from the sun in day nurseries, infant schools, and primary and secondary schools where children spend most of their day and this should be made a government policy.

\section{Ethics}

Ethics Committee Approval: The study was approved by the Local Ethics Committee of Süleyman Demirel University (Protocol number: 3/07.03.2012), Informed Consent: Consent form was filled out by all participants.

Peer-review: Externally peer-reviewed.

\section{Authorship Contributions}

Concept: Sevim Terzi, Pınar Yüksel Başak, Design: Sevim Terzi, Pınar Yüksel Başak, Data Collection or Processing: Sevim Terzi, Analysis or Interpretation: Sevim Terzi, Pınar Yüksel Başak, Ijlal Erturan, Literature Search: Sevim Terzi, Writing: Sevim Terzi, Pınar Yüksel Başak, ljlal Erturan.

Conflict of Interest: No conflict of interest was declared by the authors. Financial Disclosure: The authors declared that this study received no financial support.

\section{References}

1. Ilter NN, Öztaş MO, Adışen E, ve ark: Ankara'da bir alışveriş merkezinde yapılan nevüs taramasında popülasyonun güneşten korunma alışkanlıkları ve melanositik nevüslarının değerlendirilmesi. Türkderm 2009;43:155-9.

2. Wolpowitz D, Gilchrest BA: The vitamin D questions: how much do you need and how should you get it? J Am Acad Dermatol 2006;54:301-17.

3. Akkaya VB, Erturan i: Güneşten koruyucuların immün fonksiyonlar üzerine etkileri. T Klin J Cosmetol 2004;5:167-72.

4. Stephen A, Clarke VA: Suntanning and sun protection: a review of the psychological literature. Soc Sci Med 1995;40:265-74.

5. Güngör E: Ultraviyole radyasyonu ve foto yaşlanma. Turkiye Klinikleri J Cosm Dermatol-Special Topics 2010;3:22-6.

6. Filiz TM, Cinar N, Topsever P, Ucar F: Tanning youth: knowledge, behaviors and attitudes toward sun protection of high school students in Sakarya, Turkey. J Adolesc Health 2006;38:469-71.

7. Kaymak Y, Tekbaş ÖF, Şimşek I: Üniversite öğrencilerinin güneşten korunma ile ilgili bilgi tutum ve davranışları. Türkderm 2007;41:81-5.

8. Köktürk $A, B a z K$, Buğdaycı $R$, ve ark: Dermatoloji polikliniğine başvuran hastalarda güneşten korunma bilinci ve alışkanlıkları. Türkderm 2002;12:198203.

9. Ergin A, Bozkurt Ail, Bostancı M, Önal Ö: Beş yaşından küçük çocuğu olan annelerin güneşin sağlığa etkisine yönelik bilgi ve davranışlarının belirlenmesi. Pamukkale Tip Dergisi 2011;4:72-8.

10. Kaptanoğlu AF, Dalkan C, Hıncal E: Kuzey Kıbrıs Türk Toplumunda Güneşten Korunma: Illkokul Çağı Çocukları ve Ailelerinin Güneşten Korunma ile Illgili Bilgi, Tutum ve Davranışları. Türkderm 2012;46:121-9. 
11. Yan $S$, Xu F, Yang $C$, et al: Demographic differences in sun protection beliefs and behavior: a community-based study in Shanghai, China. Int J Environ Res Public Health 2015;12:3232-45.

12. Stanton WR, Janda M, Baade PD, Anderson P: Primary prevention of skin cancer: a review of sun protection in Australia and internationally. Health Promot Int 2004;19:369-78.

13. Owen T, Fitzpatrick D, Dolan O, Gavin A: Knowledge, attitudes and behaviour in the sun: the barriers to behavioural change in Northern Ireland. Ulster Med J 2004;73:96-104.

14. Lee $A$, Garbutcheon-Singh KB, Dixit $S$, et al: The influence of age and gender in knowledge, behaviors and attitudes towards sun protection: a cross-sectional survey of Australian outpatient clinic attendees. Am J Clin Dermatol 2015;16:47-54.

15. Turhan Haktanır N, Yazıcı S: Ebeveynlerin sosyal, ekonomik ve kültürel düzeylerinin çocukları güneşin zararlı etkilerinden koruma üzerine etkileri. Çocuk Dergisi 2008;8:160-5.

16. Pengpid $S$, Peltzer $\mathrm{K}$ : Sun protection use behaviour among University students from 25 low, middle income and emerging economy countries. Asian Pac J Cancer Prev 2015;16:1385-9.
17. Yurtseven E, Ulus T, Vehid S, et al: Assessment of knowledge, behaviour and sun protection practices among health services vocational school students. Int J Environ Res Public Health 2012;9:2378-85.

18. Hutchinson AD, Prichard I, Ettridge K, Wilson C: Skin Tone Dissatisfaction, Sun Exposure, and Sun Protection in Australian Adolescents. Int J Behav Med 2015;22:435-42.

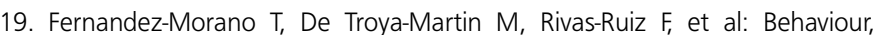
attitudes and awareness concerning sun exposure in adolescents on the Costa del Sol. Eur J Dermatol 2014;24:85-93.

20. Pruim B, Wright L, Green A: Do people who apply sunscreens, re-apply them? Australas J Dermatol 1999;40:79-82.

21. Laniauskaite I, Ozalinskaite A, Strupaite R, Bylaite M: Skin cancer knowledge, attitude and behavior towards sun exposure among young adults in Lithuania. Dermatol Online 2011;2:189-95.

22. Johnson K, Davy L, Boyett $T$, et al: Sun protection practices for children: knowledge, attitudes, and parent behaviors. Arch Pediatr Adolesc Med 2001;155:891-6 